\title{
The Emergence of Extended-Spectrum $\beta$-Lactamase Producing and Hybrid Pathotypes of Escherichia Coli Isolates from Diarrheic Human Cases: A New Public Health Concern in Iran
}

\section{Zahra Asadi}

Shahid Bahonar University of Kerman

Reza Ghanbarpour

Shahid Bahonar University of Kerman

Davood Kalantar-Neyestanaki

Kerman University of Medical Sciences

Hesam Alizade ( $\sim$ alizade.h2000@yahoo.com )

Hormozgan University of Medical Sciences https://orcid.org/0000-0002-8050-836X

\section{Research}

Keywords: $\beta$-lactamase, hybrid, pathotype, Escherichia coli, diarrhea

Posted Date: July 28th, 2021

DOl: https://doi.org/10.21203/rs.3.rs-746606/v1

License: (c) (1) This work is licensed under a Creative Commons Attribution 4.0 International License.

Read Full License 


\section{Abstract}

Background: Intra-intestinal pathogenic strains of Escherichia coli are responsible for mild to severe gastrointestinal lesions, which are mediated by various virulence factors. In this study, we have focused on a comprehensive set of E. coli pathotypes, including STEC, EPEC, EHEC, ETEC, and some hybrid pathotypes including, STEC/ ETEC, EHEC/ ETEC, and EPEC/ ETEC.

Methods: Totally, 467 stool samples were obtained from gastrointestinal patients during four years (2016 to 2020). Four pathotypes of E. coli (EPEC, ETEC, EHEC, STEC) were screened due to six virulence genes, including eae, st 1 , stx2, st, and It using the conventional PCR method. Finally, detected $E$. coli pathotypes were subjected to determine phenotypic and genotypic $\beta$-lactam resistance properties.

Result: In this study 59/467 (12.63\%) strains belonged four pathotypes including STEC (20/59; 50.8\%), $\operatorname{EPEC}(11 / 59 ; 18.6 \%), \operatorname{ETEC}(8 / 59$ 13.5\%), EHEC (5/59; 8.4\%) and three novel hybrid pathotypes including STEC/ETEC (3/59; 5\%), EHEC/ETEC (1/59; $1.6 \%)$, and EPEC/ETEC (1/59; $1.6 \%)$. Totally $23 / 59$ (38.9\%) isolates were identified as ESBL-producing.

Conclusion: Transmission of virulence and antibiotic resistance genes among $E$. coli strains lead to the emergence of antimicrobial-resistant hybrid pathogenic strains, which is an important health concern. According to food-born and fecal-oral transmission of these E. coli strains, standard methods should be performed to eliminate the possible contamination of food, equipment, and living environment to manure and feces.

\section{Background}

Diarrhea is one of the most common syndromes due to gastrointestinal infections, which could lead to hospitalization and death among children and the elderly worldwide [1, 2]. Infectious diarrhea caused by more than one bacterial agent can be responsible for severe clinical symptoms in children [1, 2]. Among the bacterial species, Escherichia coli can be considered as one of the most prevalent causes (Sjöling, Sadeghipoorjahromi, Novak, \& Tobias, 2015). Diarrheagenic E. coli (DEC) could be classified into seven main pathotypes, which include Enterotoxigenic E. coli (ETEC), Enteropathogenic E. coli (EPEC), Enteroinvasive E. coli (EIEC), Enteroaggregative E. coli (EAEC), Diffusely adherent E. coli (DAEC), Shigatoxin producing E. coli (STEC) which include a sub-pathotype called Enterohemorrhagic E. coli (EHEC) and adherent-invasive E. coli (AIEC) [5].

In this work, four pathotypes of DEC, including ETEC, EPEC, STEC, and EHEC, were considered for molecular characterization. ETECs cause watery diarrhea in travelers, especially in children in low and middle-income countries. Genetic diagnostic keys are based on the presence of heat-labile and/or heatstable enterotoxin encoding genes, including $/ t$ and $s t$, respectively [6]. EPEC infection in human leads to watery diarrhea in children via virulence factors which encoded by the genes on the chromosomal locus of enterocyte effacement (LEE) pathogenicity island such as eae, which encodes intimin [7]. STEC pathotype is usually responsible for self-limiting mild to severe bloody diarrhea. STECs are genetically 
detected based on the presence of one or both stx 1 and $s t \times 2$ genes, encoding Shiga toxins. STEC has a sub-pathotype named EHEC, which produces Shiga toxin and intimin simultaneously. The strains of EHEC could cause hemorrhagic colitis (HC) and hemolytic uremic syndrome (HUS) $[1,7,8]$.

E. coli strains harbor some virulence genes associated with two or more DEC pathotypes called hybrid pathotypes of $E$. coli. The combination of virulence factors has been mostly led to more severe intestinal infections. Some examples of hybrid pathotypes that were associated with severe diseases are STEC/ETEC, EAEC/STEC, EPEC/ETEC, ExPEC/STEC, ExPEC/EHEC, EXPEC/EPEC, ExPEC/EAEC, and EXPEC/ETEC [9-11]. In 2011, an outbreak of EAEC/STEC occurred in Germany and spread out to Europe and North America; in EAEC/STEC hybrid pathotype, stx and aggR (transcriptional regulator of enteroaggregative $E$. coli) were the main virulence genetic traits that have a role in diarrhea, bloody diarrhea and HUS [12].

Antibiotic therapy in E. coli infections is commonly used for severe cases. Antimicrobial treatment of these infections faces many problems due to the emergence of antibiotics resistant strains [13]. One of the main mechanisms of antimicrobial resistance in $E$. coli is assessed against $\beta$-lactam antibiotics; this mechanism is performed through the hydrolysis of the antibiotics via $\beta$-lactamases encoded by large plasmids harboring many different resistance genes [14]. The most prominent extended-spectrum betalactamase enzymes in $E$. coli are encoded by the genes belonged to $b / a_{T E M}, b / a_{S H V}$, and bla ${ }_{C T X-M}$ types [15].

bla ${ }_{T E M}$ and $b / a_{S H V}$ genes commonly encode the beta-lactamase enzymes, which hydrolyze penicillins and first-generation cephalosporins, while the genes from the $b / a_{C T X-M}$ group usually encode the $\beta$ lactamase enzymes, which hydrolyze third-generation cephalosporin antibiotics [15].

In this study, we have focused on a comprehensive set of positive $E$. coli strains for virulence genes of STEC, EPEC, EHEC, and ETEC, which isolated from diarrheic human. We subjected these strains to investigate molecular virulence properties and antimicrobial resistance of the pathotypes and their hybrid.

\section{Methods}

\section{Fecal sampling, E. coli isolation, and DNA extraction}

A total of 467 stool samples were obtained from patients with diarrhea since from 2016 to 2020 . All samples were cultured on McConkey medium and incubated at $37^{\circ} \mathrm{C}$. After 24 hours, one suspected $E$. coli (smooth, round, and pink) colony was picked up from each plate and studied by biochemical tests (IMViC including indole, Methyl red, Voges-Proskauer, and Citrate tests) for diagnostic confirmation.

DNA of confirmed E. coli colonies were extracted by boiling method. Each colony was suspended in 350 $\mu \mathrm{l}$ distilled sterile water and boiled for $15 \mathrm{~min}$ at $98-100^{\circ} \mathrm{C}$ by heating block (Eppendorf, Germany). Then, the boiled bacterial suspensions were centrifuged at $13000 \mathrm{rpm}$ for 1-2 min (Eppendorf, Germany) and the supernatant was stored at $-20^{\circ} \mathrm{C}$ for the next steps. 


\section{Pcr For Detection Of Stec, Epec, Ehec, And Etec}

In this study, four pathotypes of E. coli were screened due to six virulence genes, including eae, stx1, stx2, $e h l y$, st, and $l t$, using the conventional polymerase chain reaction (PCR) method. These genes were detected by specific primers (Table 1) and the E. coli strains were pathotyped for EPEC (eae+), STEC (stx 1 + and/or st $x 2+$ ), and EHEC (positive strains for eae and one or both stx 1 and st 2 genes) strains. Three positive controls were used for pathotyping including ETEC H10407 (st+ and $/ t+)$ and Sakai $(s t \times 1+$, stx2+ and eae+). Finally, 59 isolates including enterotoxigenic $E$. coli $(\mathrm{n}=8)$, Shiga toxin-producing $E$. coli $(\mathrm{n}=$ $30)$, enterhemorrhagic $E$. coli $(n=5)$, enteropathogenic $E$. coli $(n=11)$, and hybrid pathotypes $(n=5)$ were subjected for more molecular characterization.

Table 1

Specific primers for detection of pathotypes and -lactamase genes.

\begin{tabular}{|c|c|c|c|c|}
\hline \multicolumn{5}{|l|}{$\boldsymbol{\beta}$} \\
\hline Gene & Sequence $(5 \rrbracket-3 \rrbracket)$ & PCR condition & $\begin{array}{l}\text { Product } \\
\text { size } \\
\text { (bp) }\end{array}$ & Reference \\
\hline \multirow[t]{2}{*}{ stx 1} & ATAAATCGCCATTCGTTGACTAC & \multirow{6}{*}{$\begin{array}{l}\text { Multiplex touchdown } \\
\text { PCR consisting } 35 \\
\text { cycles: } 95^{\circ} \mathrm{C}(1 \mathrm{~min}), \\
65^{\circ} \mathrm{C}(2 \mathrm{~min}) \text { at for first } \\
10 \text { cycles decreasing to } \\
60^{\circ} \mathrm{C} \text { by cycle } 15,72^{\circ} \mathrm{C} \\
(1.5 \text { min for first } 25 \\
\text { cycles and } 2.5 \text { min } \\
\text { from cycles } 25-35) \text {. }\end{array}$} & \multirow[t]{2}{*}{180} & \multirow{2}{*}{$\begin{array}{l}\text { Askari } \\
\text { badoui } \\
2015\end{array}$} \\
\hline & AGAACGCCCACTGAGATCATC & & & \\
\hline \multirow[t]{2}{*}{ stx2 } & GGCACTGTCTCTCTGAAACTGCTCC & & \multirow[t]{2}{*}{255} & \multirow{2}{*}{$\begin{array}{l}\text { Askari } \\
\text { badoui } \\
2015\end{array}$} \\
\hline & TCGCCAGTTATCTGACATTCTG & & & \\
\hline \multirow[t]{2}{*}{ Eae } & GACCCGGCACAAGCATAAGC & & \multirow[t]{2}{*}{384} & \multirow{2}{*}{$\begin{array}{l}\text { Askari } \\
\text { badoui } \\
2015\end{array}$} \\
\hline & CCACCTGCAGCAACAAGAGG & & & \\
\hline \multirow[t]{2}{*}{ St } & ATTTTTCTTTCTGTATTGTCTT & \multirow{2}{*}{$\begin{array}{l}30 \text { cycles: } 95^{\circ} \mathrm{C}(30 \mathrm{~s}), \\
60^{\circ} \mathrm{C}(30 \mathrm{~s}), 72^{\circ} \mathrm{C}(30 \mathrm{~s})\end{array}$} & \multirow[t]{2}{*}{190} & \multirow{2}{*}{$\begin{array}{l}\text { Alizade } \\
2017\end{array}$} \\
\hline & CACCCGGTACAAGCAGGATT & & & \\
\hline \multirow[t]{2}{*}{$L t$} & GGCGACAGATTATACCGTGC & \multirow{2}{*}{$\begin{array}{l}30 \text { cycles: } 95^{\circ} \mathrm{C}(30 \mathrm{~s}) \\
60^{\circ} \mathrm{C}(30 \mathrm{~s}), 72^{\circ} \mathrm{C}(30 \mathrm{~s})\end{array}$} & \multirow[t]{2}{*}{450} & \multirow{2}{*}{$\begin{array}{l}\text { Alizade } \\
2017\end{array}$} \\
\hline & CGGTCTCTATATTCCCTGTT & & & \\
\hline \multirow[t]{2}{*}{ bla $_{T E M}$} & GCGGAACCCCTATTTG & \multirow{2}{*}{$\begin{array}{l}35 \text { cycles: } 95^{\circ} \mathrm{C}(30 \mathrm{~s}), \\
50^{\circ} \mathrm{C}(30 \mathrm{~s}), 72^{\circ} \mathrm{C}(60 \mathrm{~s})\end{array}$} & \multirow[t]{2}{*}{963} & \multirow{2}{*}{$\begin{array}{l}\text { Roschanski } \\
2014\end{array}$} \\
\hline & ACCAATGCTTAATCAGTGAG & & & \\
\hline \multirow[t]{2}{*}{$b^{\prime} a_{S H V}$} & TTATCTCCCTGTTAGCCACC & \multirow{2}{*}{$\begin{array}{l}35 \text { cycles: } 95^{\circ} \mathrm{C}(30 \mathrm{~s}) \\
50^{\circ} \mathrm{C}(30 \mathrm{~s}), 72^{\circ} \mathrm{C}(60 \mathrm{~s})\end{array}$} & \multirow[t]{2}{*}{795} & \multirow{2}{*}{$\begin{array}{l}\text { Roschanski } \\
2014\end{array}$} \\
\hline & GATTTGCTGATTTCGCTCGG & & & \\
\hline \multirow[t]{2}{*}{ bla $_{C T X-M}$} & CGATGTGCAGTACCAGTAA & \multirow{2}{*}{$\begin{array}{l}35 \text { cycles: } 95^{\circ} \mathrm{C}(30 \mathrm{~s}) \\
60^{\circ} \mathrm{C}(30 \mathrm{~s}), 72^{\circ} \mathrm{C}(60 \mathrm{~s})\end{array}$} & \multirow[t]{2}{*}{585} & \multirow{2}{*}{$\begin{array}{l}\text { Roschanski } \\
2014\end{array}$} \\
\hline & TTAGTGACCAGAATCAGCGG & & & \\
\hline
\end{tabular}




\section{Phenotypic And Genotypic $\beta$-lactam Resistance}

Determination of phenotypic antibiotic resistance was performed according to the Kirby-Bauer disk diffusion scheme and CLSI 2021 for all strains [49]. Antibiotic discs of ceftazidime (30 $\mu \mathrm{g})$, ceftazidime/clavulanic acid ( $30 \mu \mathrm{g} / 10 \mu \mathrm{g})$, cefotaxime $(30 \mu \mathrm{g})$, and cefotaxime/clavulanic acid (30 $\mu \mathrm{g} / 10 \mu \mathrm{g}$ ) were placed on Mueller-Hinton agar plates inoculated by swab contaminated to $E$. coli suspensions with $0.5 \mathrm{McF}$ arland turbidity $\left(\mathrm{OD}_{625 \mathrm{~nm}}=0.08\right.$ to 0.1$)$ that obtained from overnight $37^{\circ} \mathrm{C}$ incubation. After $24 \mathrm{~h}$ incubation at $37^{\circ} \mathrm{C}, \mathrm{a} \geq 5 \mathrm{~mm}$ increase in zone diameter for cefotaxime-clavulanate vs. the zone diameter of cefotaxime and/or a $\geq 5 \mathrm{~mm}$ increase in zone diameter for ceftazidimeclavulanate vs. the zone diameter of ceftazidime was considered as ESBL-producing strain. Quality control of antimicrobial resistance tests was carried out using E. coli ATCC 25922 standard strain. All 59 E. coli strains were screened for bla $a_{T E M}, b / a_{S H V}$, and $b / a_{C T X-M}$ genes by PCR method. These genes were detected by specific primers, which have been described in Table 1. Positive strains for bla ${ }_{T E M}$ were $E$. coli 35218 and for bla $a_{S H V}$ and $b / a_{C T X-M}$ was Klebsiella 700603.

\section{Results}

In this study, 59 DEC strains (12.63\%) were detected from 467 E. coli isolates collected during four years. All prevalence rates have calculated according to 59 isolates as sample size; among 59 DEC strains, the pathotypes STEC, EPEC, ETEC, EHEC, STEC/ETEC, EHEC/ETEC, and EPEC/ETEC were detected with $50.8 \%, 18.6 \%, 13.5 \%, 8.4 \%, 5 \%, 1.6 \%$ and $1.6 \%$ frequency, respectively (Fig. 1). These pathotypes had been identified based on associated virulence genetic markers including stx 1 (33.5\%), stx2 (37.2\%), eae (30.5\%), It (6.7\%) and st (22\%) (Table 2). Twelve virulence gene combination profiles were observed which nine of them including eae (EPEC), stx1 (STEC), stx2 (STEC), stx1/stx2 (STEC), stx1/eae (EHEC), stx2/eae (EHEC), stx1/stx2/eae (EHEC), st (ETEC) and It/st (ETEC) belonged to one of the main pathotypes of DECs and three of them including stx1/st, eae/st and stx1/eae/st belonged to novel hybrid pathotypes including STEC/ETEC, EPEC/ETEC, and EHEC/ETEC, respectively (Table 2 and Fig. 1). 
Table 2

Prevalence of virulence genes, virulence gene profiles, resistance genes, and resistance gene profiles of E. coli isolates

\begin{tabular}{|c|c|c|}
\hline Variables & No. $(\%)$ & $95 \%$ confidence interval \\
\hline \multicolumn{3}{|l|}{ Virulence genes } \\
\hline stx 1 & $21(35.59)$ & $23.55 \%-49.13 \%$ \\
\hline stx2 & $22(37.29)$ & $25.04 \%-50.85 \%$ \\
\hline Eae & $18(30.51)$ & $19.19 \%-43.87 \%$ \\
\hline St & $13(22.03)$ & $12.29 \%-34.73 \%$ \\
\hline$L t$ & $4(6.78)$ & $1.88 \%-16.46 \%$ \\
\hline \multicolumn{3}{|c|}{ Virulence gene profiles (pathotype) } \\
\hline eae (EPEC) & $11(18.64)$ & $9.96 \%-30.91 \%$ \\
\hline stx 1 (STEC) & $11(18.64)$ & $9.96 \%-30.91 \%$ \\
\hline stx2 (STEC) & $17(28.81)$ & $17.76 \%-42.08 \%$ \\
\hline stx $1 / s t \times 2$ (STEC) & $2(3.39)$ & $0.41 \%-11.71 \%$ \\
\hline stx1/eae (EHEC) & $3(5.08)$ & $1.06 \%-14.1 \%$ \\
\hline stx2/eae (EHEC) & $1(1.69)$ & $0.04 \%-9.09 \%$ \\
\hline stx1/stx2/eae (EHEC) & $1(1.69)$ & $0.04 \%-9.09 \%$ \\
\hline st (ETEC) & $4(6.78)$ & $1.88 \%-16.46 \%$ \\
\hline It/st (ETEC) & $4(6.78)$ & $1.88 \%-16.46 \%$ \\
\hline stx1/st (STEC/ETEC) & $3(5.08)$ & $1.06 \%-14.15 \%$ \\
\hline eae/st (EPEC/ETEC) & $1(1.69)$ & $0.04 \%-9.09 \%$ \\
\hline stx1/eae/st (EHEC/ETEC) & $1(1.69)$ & $0.04 \%-9.09 \%$ \\
\hline \multicolumn{3}{|l|}{ Resistance genes } \\
\hline bla $_{T E M}$ & $58(98.31)$ & $90.91 \%-99.96 \%$ \\
\hline bla $_{S H V}$ & $3(5.08)$ & $0.41 \%-11.1 \%$ \\
\hline bla $_{C T X-M}$ & $11(18.64)$ & $9.96 \%-30.91 \%$ \\
\hline \multicolumn{3}{|l|}{ Resistance gene profiles } \\
\hline bla $_{T E M}$ & $46(77.96)$ & $65.27 \%-87.71 \%$ \\
\hline
\end{tabular}




\begin{tabular}{|lll|}
\hline Variables & No. (\%) & 95\% confidence interval \\
\hline bla $_{T E M} / b / a_{S H V}$ & $1(1.69)$ & $0.04 \%-9.09 \%$ \\
\hline bla $_{T E M} /$ bla & & \\
\hline CTX-M & $9(15.25)$ & $6.08 \%-24.43 \%$ \\
\hline Without resistance gene & $1(1.69)$ & $0.04 \%-9.09 \%$ \\
\hline
\end{tabular}

Antimicrobial resistances of the pathotypes were estimated against $\beta$-lactam antibiotics, phenotypically and genotypically. Among the 59 virulent strains, 23 isolates (37.28\%) were detected as ESBL-producing. These ESBL-positive strains belonged to EHEC $(1 / 5 ; 20 \%)$, EHEC/ETEC $(1 / 1 ; 100 \%)$, EPEC $(6 / 11 ; 54.5 \%)$, EPEC/ETEC (1/1; 100\%), ETEC (2/8; 25\%), STEC (10/30; 33.3\%) and STEC/ETEC (2/3; 66.6\%).

Among the fifty-nine virulent strains, we observed a high rate $(23 / 59 ; 38.9 \%)$ of phenotypic resistant $E$. coli isolates against $\beta$-lactam antibiotics; fifteen $(15 / 23 ; 65.2 \%)$ were positive for bla $a_{\text {TEM }}$ four $(4 / 23$; $17.3 \%)$ were positive for bla $a_{T E M} /$ bla ${ }_{C T X-M}$ two $(2 / 23 ; 8.6 \%)$ for bla $a_{T E M} / b / a_{S H V} / b / a_{C T X-M}$ and one $(1 / 23$; $4.3 \%$ ) for bla $a_{T E M} / b_{S H}$. Most of our hybrid pathotypes $(4 / 5 ; 80 \%)$, including EPEC/ETEC (1 isolate), STEC/ETEC (2 isolates), and EHEC/ETEC (1 isolate), were estimated as ESBL-producing. Three of four ESBL-producing hybrid pathotypes were positive for $b / a_{T E M} / b / a_{C T X-M}$ gene combination and one of them was only positive $b / a_{T E M}$. Totally, we identified ESBL-producing in typical pathotypes including STEC (10/23; 43.7\%), EPEC (6/23; 26\%), ETEC (2/23; 8.6\%) and EHEC $(1 / 23 ; 4.3 \%)$. In this research, we found one STEC and one ETEC, which were positive for the production of ESBLs and $b / a_{T E M} / b / a_{S H V} / b^{\prime} / a_{C T X} M$ gene profile. The distribution pattern of pathotypes among ESBL-negative strains is approximately different. Among 36 ESBL-negative strains, 20 STECs (56.3\%), 6 ETECs (16.4\%), 5 EPECs (13.7\%), 4 EHECs (11.1\%) and one hybrid pathotype (STEC/ETEC; $2.5 \%$ ) were detected (Table 3).

Table 3

Virulence gene profiles, antimicrobial resistance gene patterns, and ESBL production of hybrid E. coli pathotypes

\begin{tabular}{|c|c|c|c|c|c|c|}
\hline Hybrid pathotypes & $s t \times 1$ & Eae & st & $b^{\prime} a_{T E M}$ & bla & ESBL \\
\hline STEC/ETEC & + & & + & + & & + \\
\hline STEC/ETEC & + & & + & + & + & + \\
\hline STEC/ETEC & + & & + & + & & \\
\hline EPEC/ETEC & & + & + & + & + & + \\
\hline EHEC/ETEC & + & + & + & + & & + \\
\hline
\end{tabular}

\section{Discussion}


Knowledge of the epidemiology of infections associated with E. coli pathotypes is very crucial for health policymakers [16]. Consequently, the results of the present work may assist to epidemiological and therapeutic perspectives. The prevalence of diarrheagenic $E$. coli strains in this study is similar to some countries such as Colombia (14.4\%) and is comparable with the other reports from India (26\%), Iran (34\%), USA (5.5\% and $19 \%)$, etc. [17-21].

In our study, the most prevalent pathotype was STEC, the positive strains for st $x 1$ and/or stx 2 genes. There was no significant difference between the prevalence of $s t \times 1$ and stx 2 genes, while some previous studies have been reported the predominance of $s t x 1$ genes $[22,23]$. STEC strains to harbor the $s t x 1$ gene are frequently responsible for non-complicated diarrhea to asymptomatic infections, while the stx2 gene is mainly associated with severe cases of diarrhea and HUS $[23,24]$.

In this research, some STEC strains (less than 10\%) carried eae gene, which were identified as EHEC pathotypes. Reports from EHECs in Iran is rare [17, 25], while annually, more than 70,000 cases of EHEC infections transmitted to human by the routes of foodborne, person-to-person, waterborne, animal contact and laboratory-related are recorded in the USA by Centers for Disease Control and Prevention (CDC) [26]. From 2006 to 2010, there were 254 cases of EHEC infections with an average prevalence rate of 0.11 per 100,000 populations in Korea and 20,883 cases with an average prevalence of 3.26 per 100,000 populations [27].

The strains which are positive for the eae gene and negative for stx genes belong to EPEC. Virulence genes on the LEE (locus of enterocyte effacement) pathogenicity island in EPECs cause attaching and effacing lesions on enterocytes. This pathotype had the second highest frequency in this work; our results are comparable with the results reported by Usein et al. [28]. In a systematic review, the presence of EPECs has been estimated from $0.00 \%$ to approximately $60 \%$ among $E$. coli isolated from urinary tract infection, diarrheic and healthy cases in Iran [29]. EPEC pathotype is an important cause of mild-to-severe loose/watery stools, especially in children with fecal-oral, Human-to-human, and animal-to-human transmission.

The third prevalent pathotype of this study was ETEC causing moderate-to-severe diarrhea in human. The profiles $s t /$ it and st were the most common toxigenic genotype among ETECs, which agrees with Bhakat et al. (2019) [30]. None of the strains carried the /t gene alone, which is in contrast with the global prevalence of the gene where the presence of $I t$ is higher than $s t$ or $s t / I t$ profile [31]. It has been reported that positive ETECs for $s t /$ /t profile are more often associated with a higher risk of death in young children $[22,32,33]$. The prevalence of ETECs in this study is similar to some countries such as India $(13.6 \%)$. It is comparable with the other reports from Argentina (18.3\%) and Vietnam (2.2\%) [34,35]. During 2016 to 2017, 244 cases of ETEC has been detected from Minnesota [36]; the incidence rate of ETEC in the USA has been estimated as 250 per 100,000 population in the USA within all age groups and in both males and females [37]. In a systematic review that has been performed in Iran, the frequency of ETEC was $16 \%$ according to 5669 isolates in 28 publications [29]. Differences in the prevalence rates of E. coli 
pathotypes found in the present and previous studies may be associated with geographical locations, study methods, public health, and host factors.

Specific virulence genes of pathotypes are mostly on mobile genetic elements such as phages and plasmids as identified previously in STECs and ETECs [38]. So horizontal gene transmissions between various pathotypes lead to combine the virulence factors and emerge hybrid pathotypes, which in some studies named hetero-pathogenic $E$. coli strains with more potential to cause more severe infections [5]. There is low information about the incidence of hybrid pathotypes in Iran; one EPEC/ETEC strain (positive for intimin and heat-stable ) and one EHEC/ETEC strain (positive for Shiga toxin, intimin and heat-stable toxins) were detected from healthy cattle in 2016 [39]. In our study, we detected some hybrid pathotypes of $E$. coli for the first time in human in Iran; we found three virulence profiles, including eae/st (EPEC/ETEC), stx1/st (STEC/ETEC), and stx1/eae/st (EHEC/ETEC). Best of our knowledge, there are still no reports of EHEC/ETEC strains in human from other countries.

There is a report about the identification of EPEC/ETEC strains in the USA which is isolated from diarrheic, asymptomatic, and death cases in children [40]. In Finland and Sweden, STEC/ETEC strains were isolated from $2.05 \%$ of clinical strains initially characterized as STEC during 15 years [38, 41]. Many researches have revealed a high frequency of STEC/ETEC isolates from ruminants and piglets, showing the importance of animals as the main reservoirs for the hybrid pathotypes [5]. The emergence of multiple virulent pathogens is a new and very critical public health concern. So, characterization of genotypic and phenotypic virulence and antimicrobial resistance of single and hybrid pathotypes is an important and necessary for surveillance, treatment, and control of related infections.

DEC strains can be sources for antibiotic resistance genes [42]. Interestingly, ESBL production was determined phenotypically in approximately thirty-seven percent of our isolates. In a similar study, $60.6 \%$ frequency of ESBL positive strains have been stated by Khairy et al. (2020) in Egypt [16]. In view of the genes encoding ESBLs, Khoshvaght et al. (2014) reported a high prevalence of bla genes in EAEC isolates (78.9\% and 63.1\%, respectively) [43]. Ali et al. (2014) found more than 78\% of EAEC and none of the EPEC isolates carried ESBL genes [44]. Findings of a study performed by Zhou et al. (2018) showed a very high percentage (93.3\%) of ESBL genes among E. coli pathotypes [45] which confirms our findings, especially about $b a_{T E M}$. The occurrence of resistant hybrid pathotypes of $E$. coli could be related to horizontal gene transmission among various clones [11]. For example, García et al. (2018) detected a STEC/ETEC isolate from diarrheic pig harboring a plasmid containing multiple resistance genes and multiple virulence genes [46]. Generally, the emergence of antimicrobial resistance might result from excessive consumption of antimicrobials without a doctor's supervision [47]. The unplanned use of antibiotics over the past decades has exposed the population of bacteria in the human's normal flora to selective pressure in favor of resistant bacterial strains. Today, this phenomenon has led to antibiotic resistance and even multi-drug resistance among bacterial pathogens [48].

\section{Conclusion}


Genetic factors associated with virulence and antibiotic resistance are exchanged among $E$. coli strains.

Therefore, the emergence of hybrid pathogenic strains and resistance to antibiotics is an important health concern. This study identified several ESBL-producing hybrid pathogenic E. coli strains that could be hazardous for public health. Since the transmission of these strains could be food-born and fecal-oral, so standard methods should be considered to eliminate possible contamination of food, equipment, and living environment to manure and feces.

\section{Declarations}

\section{Ethics declarations}

All experimental protocols were approved by the committee for ethics in biomedical research in Veterinary Faculty of Shahid Bahonar University of Kerman, Iran. Also, all methods were carried out in accordance with relevant guidelines and regulations presented by Iran National Committee for Ethics in Biomedical Research.

\section{Consent for publication}

Not applicable.

\section{Availability of data and materials}

All data generated or analyzed during this study are available from the corresponding authors on reasonable request.

\section{Competing of interests}

The authors declare that they have no competing interests.

\section{Funding}

This research received no specific grant from any funding agency.

\section{Authors' contributions}

$R G, H A$, and DK participated in the study design. ZA, RG, and HA performed sampling and the laboratory tests. ZA, RG, and HA wrote the manuscript. All authors read and approved the final manuscript.

\section{Acknowledgments}

The authors would like to express their gratitude to personals of microbiology laboratory of Faculty of Veterinary Medicine in Shahid Bahonar University of Kerman for their assistance in this research.

\section{References}


1. Msolo L, Iweriebor BC, Okoh Al. Pervasiveness of diarrheagenic E. coli pathotypes and Salmonella species among gastroenteritis patients in some selected pastoral hinterlands of the Amathole district municipality, Eastern Cape, South Africa. Hum Microbiome J. 2020;17:100074.

2. Uppal B, Perween N, Aggarwal P, Kumar SK. A comparative study of bacterial and parasitic intestinal infections in India. J Clin diagn Res. 2015;9:DC01-4.

3. Rossit ARB, Gonçalves ACM, Franco C, Machado RLD. Etiological agents of diarrhea in patients infected by the human immunodeficiency virus-1: a review. Rev Inst Med Trop Sao Paulo. 2009;51:59-65.

4. Sjöling Å, Sadeghipoorjahromi L, Novak D, Tobias J. Detection of major diarrheagenic bacterial pathogens by multiplex PCR panels. Microbiol Res. 2015;172:34-40.

5. de Mello Santos AC, Santos FF, Silva RM, Gomes TAT. Diversity of hybrid-and hetero-pathogenic Escherichia coli and their potential implication in more severe diseases. Front Cell Infect Microbiol. 2020;10:339.

6. Youmans BP, Ajami NJ, Jiang Z-D, Petrosino JF, DuPont HL, Highlander SK. Development and accuracy of quantitative real-time polymerase chain reaction assays for detection and quantification of enterotoxigenic Escherichia coli (ETEC) heat labile and heat stable toxin genes in travelers' diarrhea samples. Am J Trop Med Hyg. 2014;90:124-32.

7. Jesser KJ, Levy K. Updates on defining and detecting diarrheagenic Escherichia coli pathotypes. Curr Opin Infect Dis. 2020;33:372-80.

8. Ud-Din A, Wahid S. Relationship among Shigella spp. and enteroinvasive Escherichia coli (EIEC) and their differentiation. Brazilian J Microbiol. 2014;45:1131-8.

9. Bielaszewska M, Mellmann A, Zhang W, Köck R, Fruth A, Bauwens A, Peters G, Karch H. Characterisation of the Escherichia coli strain associated with an outbreak of haemolytic uraemic syndrome in Germany, 2011: a microbiological study. Lancet Infect Dis. 2011;11:671-6.

10. Mellmann A, Harmsen D, Cummings CA, Zentz EB, Leopold SR, Rico A, Prior K, Szczepanowski R, Ji Y, Zhang W, McLaughlin SF. Prospective genomic characterization of the German enterohemorrhagic Escherichia coli 0104: H4 outbreak by rapid next generation sequencing technology. PLoS One. 2011;6:e22751.

11. Rasko DA, Webster DR, Sahl JW, Bashir A, Boisen N, Scheutz F, Paxinos EE, Sebra R, Chin CS, Iliopoulos D, Klammer A. Origins of the E. coli strain causing an outbreak of hemolytic-uremic syndrome in Germany. N Engl J Med. 2011;365:709-17.

12. Frank C, Werber D, Cramer JP, Askar M, Faber M, an der Heiden M, Bernard H, Fruth A, Prager R, Spode A, Wadl M. Epidemic profile of Shiga-toxin-producing Escherichia coli 0104: H4 outbreak in Germany. N Engl J Med. 2011;365:1771-80.

13. Wellington EMH, Boxall ABA, Cross P, Feil EJ, Gaze WH, Hawkey PM, Johnson-Rollings AS, Jones DL, Lee NM, Otten $\mathrm{W}$, Thomas $\mathrm{CM}$. The role of the natural environment in the emergence of antibiotic resistance in Gram-negative bacteria. Lancet Infect Dis. 2013;13:155-65. 
14. Falagas ME, Karageorgopoulos DE. Extended-spectrum $\beta$-lactamase-producing organisms. J Hosp Infect. 2009;73:345-54.

15. Khan MA, Thurgood NE, Faheem SM, Rais N, Ansari MZ, Kaleem SM, Khan ST. Occurrence of Extended Spectrum Beta-Lactamase Gram-Negative Bacteria from Non-Clinical Sources in Dubai, United Arab Emirates. Water. 2020;12:2562.

16. Khairy RMM, Fathy ZA, Mahrous DM, Mohamed ES, Abdelrahim SS. Prevalence, phylogeny, and antimicrobial resistance of Escherichia coli pathotypes isolated from children less than 5 years old with community acquired-diarrhea in Upper Egypt. BMC Infect Dis. 2020;20:1-9.

17. Moshtagian F, Alipour M, Yahyapour Y. Prevalence of Escherichia coli pathotypes among children with diarrhea in Babol, Northern Iran. Int J Enteric Pathog. 2016;4:1-4.

18. Hegde A, Ballal M, Shenoy S. Detection of diarrheagenic Escherichia coli by multiplex PCR. Indian J Med Microbiol. 2012;30:279-84.

19. Gómez-Duarte OG, Arzuza O, Urbina D, Bai J, Guerra J, Montes O, Puello M, Mendoza K, Castro GY. Detection of Escherichia coli enteropathogens by multiplex polymerase chain reaction from children's diarrheal stools in two Caribbean-Colombian cities. Foodborne Pathog Dis. 2010;7:199-206.

20. Imdad A, Foster MA, Iqbal J, Fonnesbeck C, Payne DC, Zhang C, Chappell JD, Halasa N, GómezDuarte OG. Diarrheagenic Escherichia coli and acute gastroenteritis in children in Davidson County, Tennessee, United States: a case-control study. Pediatr Infect Dis J. 2018;37:543.

21. Chao AW, Bhatti M, DuPont HL, Nataro JP, Carlin LG, Okhuysen PC. Clinical features and molecular epidemiology of diarrheagenic Escherichia coli pathotypes identified by fecal gastrointestinal multiplex nucleic acid amplification in patients with cancer and diarrhea. Diagn Microbiol Infect Dis. 2017;89:235-40.

22. Ori EL, Takagi EH, Andrade TS, Miguel BT, Cergole-Novella MC, Guth BEC, Hernandes RT, Dias RC, Pinheiro SR, Camargo CH, Romero EC. Diarrhoeagenic Escherichia coli and Escherichia albertii in Brazil: pathotypes and serotypes over a 6-year period of surveillance. Epidemiol Infect. 2019;147.

23. Vaz TMI, Irino K, Kato M, Dias ÂMG, Gomes TAT, Medeiros MIC, Rocha MM, Guth BE. Virulence properties and characteristics of Shiga toxin-producing Escherichia coli in São Paulo, Brazil, from 1976 through 1999. J Clin Microbiol. 2004;42:903-5.

24. Friedrich AW, Bielaszewska M, Zhang W-L, Pulz M, Kuczius T, Ammon A, Karch H. Escherichia coli Harboring Shiga Toxin 2 Gene Variants: Frequency and Association with Clinical Symptoms. J Infect Dis. 2002;185:74-84.

25. Badouei MA, Jajarmi M, Mirsalehian A. Virulence profiling and genetic relatedness of Shiga toxinproducing Escherichia coli isolated from humans and ruminants. Comp Immunol Microbiol Infect Dis. 2015;38:15-20.

26. Rangel JM, Sparling PH, Crowe C, Griffin PM, Swerdlow DL. Epidemiology of Escherichia coli 0157:H7 Outbreaks, United States, 1982-2002. Emerg Infect Dis. 2005;11:603-9.

27. Lee W-C, Kwon YH. Comparative study on the epidemiological aspects of enterohemorrhagic Escherichia coli infections between Korea and Japan, 2006 to 2010. Korean J Intern Med. 
2016;31:579.

28. Usein C-R, Ciontea AS, Militaru CM, Condei M, Dinu S, Oprea M, Cristea D, Michelacci V, Scavia G, Zota LC, Zaharia A. Molecular characterisation of human Shiga toxin-producing Escherichia coli 026 strains: results of an outbreak investigation, Romania, February to August 2016. Eurosurveillance. 2017;22:17-48.

29. Alizade H, Teshnizi SH, Azad M, Shojae S, Gouklani H, Davoodian P, Ghanbarpour R. An overview of diarrheagenic Escherichia coli in Iran: A systematic review and meta-analysis. J Res Med Sci. 2019;24:23.

30. Bhakat D, Debnath A, Naik R, Chowdhury G, Deb AK, Mukhopadhyay AK, Chatterjee NS. Identification of common virulence factors present in enterotoxigenic Escherichia coli isolated from diarrhoeal patients in Kolkata, India. J Appl Microbiol. 2019;126:255-65.

31. Isidean SD, Riddle MS, Savarino SJ, Porter CK. A systematic review of ETEC epidemiology focusing on colonization factor and toxin expression. Vaccine. 2011;29:6167-78.

32. Kotloff KL, Nataro JP, Blackwelder WC, Nasrin D, Farag TH, Panchalingam S, Wu Y, Sow SO, Sur D, Breiman RF, Faruque AS. Burden and aetiology of diarrhoeal disease in infants and young children in developing countries (the Global Enteric Multicenter Study, GEMS): a prospective, case-control study. Lancet. 2013;382:209-22.

33. Qadri F, Svennerholm A-M, Faruque ASG, Sack RB. Enterotoxigenic Escherichia coli in developing countries: epidemiology, microbiology, clinical features, treatment, and prevention. Clin Microbiol Rev. 2005;18:465.

34. Viboud GI, Jouve MJ, Binsztein N, Vergara M, Rivas M, Quiroga M, Svennerholm AM. Prospective cohort study of enterotoxigenic Escherichia coli infections in Argentinean children. J Clin Microbiol. 1999;37:2829-33.

35. Nguyen TV, Le Van P, Chinh Le Huy KNG, Weintraub A. Detection and characterization of diarrheagenic Escherichia coli from young children in Hanoi, Vietnam. J Clin Microbiol. 2005;43:755.

36. Buuck S, Smith K, Fowler RC, Cebelinski E, Lappi V, Boxrud D, Medus C. Epidemiology of Enterotoxigenic Escherichia coli infection in Minnesota, 2016-2017. Epidemiol Infect. 2020;148.

37. Stratton KR, Durch JS, Lawrence RS. Vaccines for the 21st Century: A Tool for Decisionmaking. National Academies Press (US); 2000.

38. Bai X, Zhang J, Ambikan A, Jernberg C, Ehricht R, Scheutz F, Xiong Y, Matussek A. Molecular characterization and comparative genomics of clinical hybrid Shiga toxin-producing and enterotoxigenic Escherichia coli (STEC/ETEC) strains in Sweden. Sci Rep. 2019;9:1-9.

39. Badouei MA, Morabito S, Najafifar A, Mazandarani E. Molecular characterization of enterohemorrhagic Escherichia coli hemolysin gene (EHEC-hlyA)-harboring isolates from cattle reveals a diverse origin and hybrid diarrheagenic strains. Infect Genet Evol. 2016;39:342-8.

40. Hazen TH, Michalski J, Luo Q, Shetty AC, Daugherty SC, Fleckenstein JM, Rasko DA. Comparative genomics and transcriptomics of Escherichia coli isolates carrying virulence factors of both enteropathogenic and enterotoxigenic E. coli. Sci Rep. 2017;7:1-17. 
41. Nyholm O, Halkilahti J, Wiklund G, Okeke U, Paulin L, Auvinen P, Haukka K, Siitonen A. Comparative genomics and characterization of hybrid Shigatoxigenic and enterotoxigenic Escherichia coli (STEC/ETEC) strains. PLoS One. 2015;10:e0135936.

42. Sommer MOA, Church GM, Dantas G. The human microbiome harbors a diverse reservoir of antibiotic resistance genes. Virulence. 2010;1:299-303.

43. Khoshvaght $\mathrm{H}$, Haghi F, Zeighami $\mathrm{H}$. Extended spectrum betalactamase producing Enteroaggregative Escherichia coli from young children in Iran. Gastroenterol Hepatol from bed to bench. 2014;7:131-6.

44. Ali MMM, Ahmed SF, Klena JD, Mohamed ZK, Moussa TAA, Ghenghesh KS. Enteroaggregative Escherichia coli in diarrheic children in Egypt: molecular characterization and antimicrobial susceptibility. J Infect Dev Ctries. 2014;8:589-96.

45. Zhou Y, Zhu X, Hou H, Lu Y, Yu J, Mao L, Mao L, Sun Z. Characteristics of diarrheagenic Escherichia coli among children under 5 years of age with acute diarrhea: a hospital based study. BMC Infect Dis. 2018;18:1-10.

46. García V, García-Meniño I, Mora A, Flament-Simon SC, Díaz-Jiménez D, Blanco JE, Alonso MP, Blanco J. Co-occurrence of mcr-1, mcr-4 and mcr-5 genes in multidrug-resistant ST10 Enterotoxigenic and Shiga toxin-producing Escherichia coli in Spain (2006-2017). Int J Antimicrob Agents. 2018;52:1048.

47. Ibrahim OM, Saber-Ayad M. Antibiotic misuse in different hospital wards (a pilot study in an Egyptian hospital). Asian J Pharm Clin Res. 2012;5:95-7.

48. Hughes D. Selection and evolution of resistance to antimicrobial drugs. IUBMB Life. 2014;66:521-9.

49. CLSI. Performance Standards for Antimicrobial Susceptibility Testing (CLSI supplement M100). 31st ed.: Clinical and Laboratory Standards Institute; 2021.

\section{Figures}
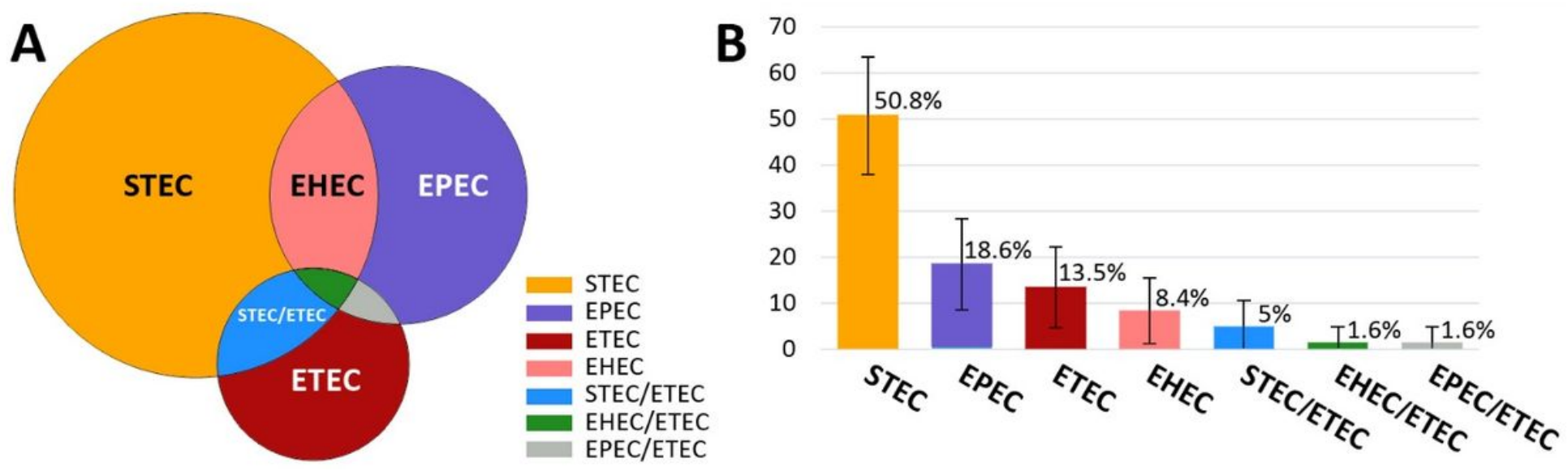

Figure 1 
Frequencies and overlaps of E. coli pathotypes. A; Venn diagram for pathotypes. B; The prevalence of E. coli pathotypes 